\title{
"SECOND CURVE" CONCEPT AS A KEY DRIVER OF ECONOMIC DEVELOPMENT IN THE EMERGING MARKETS
}

\author{
Anđelko Lojpur* \\ Ivan Radević ${ }^{* *}$ \\ Nikola Martinović ${ }^{* * *}$
}

Received: 22.7. 2020

Review

Accepted: 8. 1.2021

UDC 330.34(4-69)

DOI https://doi.org/10.30924/mjcmi.26.si.6

\begin{abstract}
"Insanity is doing the same thing over and over again and expecting different results. “
\end{abstract}

A.Einstein

\begin{abstract}
The paper begins with the understanding that the three-decade-long transition period from a socialist economy to the market one, as an integral part of comprehensive changes in Eastern Europe, both political and ideological ones, remains to be a quite problematic and ongoing process. When it comes to less-developed or transition countries, with a special focus on the Western Balkans, a popular opinion is that the impact of deindustrialization on countries in transition was as painful and radical as the "coming" of socialism. Therefore, when addressing the need for a new formula for development, it is a matter of great concern that today's multipolar world lacks well-established development paradigms, particularly taking into account an obvious stagnation in reforms, i.e. the so-called reform failure. In the

authors' opinion, it is possible to end the crisis in underdeveloped and transition countries only by introducing a "new" order, i.e. by finding a "new" economic development paradigm. In the light of the above, this paper indicates the need to replace the current transitional models of economic transformation with a turn-around strategy that would be based on reindustrialization, i.e. newly created industrial policies. Finally, this would imply the implementation of the "second curve" (the "S-curve") concept in the change management processes.

Keywords: globalization. management. neoliberalism. new industrial policies. second curve ("S-curve")

\footnotetext{
* Anđelko Lojpur, PhD, Professor, University of Montenegro, Faculty of Economics, Department of Management and Organization, Jovana Tomaševića 37, 81000 Podgorica, Montenegro, E-mail: andjelko@ucg.ac.me tion, Jovana Tomaševića 37, 81000 Podgorica, Montenegro, E-mail: radevic@ucg.ac.me

${ }^{* * *}$ Nikola Martinović, MSc, University of Montenegro, Faculty of Economics, Department of Macroeconomics, Jovana Tomaševića 37, 81000 Podgorica, Montenegro, E-mail: nikola.m@ucg.ac.me
}

** Ivan Radević, PhD, University of Montenegro, Faculty of Economics, Department of Management and Organiza-
\end{abstract}




\section{Journal of Contemporary Management Issues}

\section{INTRODUCTION}

Without prejudice to the theoretical and practical importance of the prevailing economic models of growth on a global historical level, our reasoning, to the extent that it can be argued, goes in the direction of finding a way to stop strong recession waves in less developed and transition countries. Because of many dilemmas entailed under the concept of globalization, a key question seems like a matter of logic - given the increasingly intense globalization: can the less developed countries try to make a radical break with the past in the form of a new development paradigm? In that sense, past transitional experiences clearly show that neoliberal market fundamentalism, whose roots stem from the faith in "free markets" was imposed as an ideological and political doctrine and served to economic interests of ruling political elites lingering from the communist era. This paper attempts to propose a new pattern of development to reduce macroeconomic risks to a reasonable extent, in terms of sustainable economic growth and development, as to reduce unemployment and stop further economic disparities.

This paper attempts to point out to practical applicability of the concept, called the "second curve" (the "S-curve"), regarding the future development commitments of countries in transition. The concept implies change management, in a way that the system is innovated and the existing structure changed before the development level indicates the need for change, i.e. acts proactively. Specifically, when it comes to the prevailing transitional model of economic growth and development, we would like to stress to policy decision-makers how important it is to change the paradigm (i.e. achieve the paradigm shift) because of its effects on the majority of underdeveloped and transition countries did not turn out as expected, not even after three decades of transition. In this sense, when it comes to our research methodology, in the form of predominantly qualitative analysis, we will offer a valid theoretical and practical basis for decision-makers who need to control the conceptual directions of growth and development, be it an individual development, company level (management), or the national economy (government). To communicate this and make it acceptable in practice, we have focused on the management of organizational change as an expression of "a sense of urgency", which means that only anticipated, controlled changes that are implemented at the right time, would have a controlled economic and organizational effect and will lead to changes and development (Kotter, 1996). Furthermore, using the "second curve" as an illustration of a change in the initial path (which is considered as the "first curve"), this paper defines developmental changes as a solution, not only for new problems but also as a method of maintaining and continuing the development momentum, since it has been confirmed as positive.

This paper consists of four logically connected sections. The first one is related to the impact of globalization on the development of small countries and countries in transition. The second section analyses the transition path of selected countries, with a focus on the Western Balkans, where the transition in most cases meant only stagnation. The third section addresses the necessity of new industrial policies and accepting a new development paradigm, based on the S-curve concept, while the fourth section describes examples and the impact of the new development paradigm on the microlevel, i.e. corporate management.

This study shows that small countries and countries in transition need to adopt a 
new development paradigm, which is based on the S-curve, compensating for the adverse effects of globalization. In this context, and through a comprehensive analysis, focusing on small and transition countries, the conclusions may help public administration decision-makers and corporate managers to redefine their business strategies, in the spirit of flexibility, entailed by the global business arena. Taking into account the relevance of the research and its broad scope, it provides an opportunity for many new research questions.

\section{THE IMPACT OF}

GLOBALIZATION AND THE CONCEPT OF NEOLIBERAL CAPITALISM ON LESS DEVELOPED COUNTRIES

Failed attempts to build socialism as an integral system and the triumph of liberalism were possible due to the globalization of the economy, which has become a dominant feature of modern capitalism (Lojpur \& Drašković, 2016). To begin with, and to add to the gravity that the group of countries has faced under the circumstances of the evident "failure in reform", it is worth noting the words of J. M. Keynes: "In the long run, we are all dead". It seems that we were able to grasp this truth, once the concept of neoliberal capitalism was overflown with the idea of globalization. To be able to understand more clearly what was going on in countries in transition in the meantime, it would be worth remembering the words of professor Lj. Jurčić, who pointed out that the system of workers' self-government and self-governing socialism was transformed overnight into "wild capitalism" and market fundamentalism. And, instead of relying on production, savings, investments, and exports, which are features of a typical business model, an unconventional business model was developed in the 1990s that relied on trade, consumption, and import (Jurčić, 2010). Another statement of professor Jurčić (2011) speaks in favor of this: "Croatian economy has been hit by a crisis lately, but this time it was much deeper and longer-lasting. But, these events were not limited solely to the economy as it is just one of the important components of a single social organism whose parts are all closely linked (...) Unfortunately, our 'reformers' are not ready to openly admit the implausibility and collapse of the ultraliberal ideology that led to the global crisis, and to our own, Croatian crisis, too".

Some other authors point out the necessity to change the management paradigm in the transition process, as they see it as a reaction to the new reality where the market plays the role of a key regulator of economic trends and becomes a guiding spirit of government officials in transition economies (Langer et al., 2017). The transition economies have gone through the "abortion of reforms", as confirmed in the case of Serbia that has an output gap i.e. the economic activity of Serbia is below the fairly possible level (Đuričin, 2011). The following statement supports the above: "Transitional model of economic growth", as Jakopin (2014) points out, "that was used in Serbia for thirteen years, did not give expected results". After a decade of economic distortions, the economic system was unable to balance many gaps and systemic deformations that burst out with the outbreak of economic crisis". A prominent example is the region of Southeast Europe (SEE) ... "that shows evident consequences of the transition model in all SEE countries. 'Debt economy' takes its toll in all dimensions of development, starting from regression in demography through the devastation of industry, gaps in education, 


\section{Journal of Contemporary Management Issues}

and underdevelopment of institutions" (Jakopin, 2014). Furthermore, the problems of inequality gave rise to new moral, social and political challenges (Blanchard \& Rodrik, 2021) and affected limited economic growth by reducing the economic opportunities of the lower and middle classes. Similarly, we would like to mention the opinion of Mićić (2015), who believes that "several theoretical, as well as economic realities, show that industrialization is vital for successful economic development, as it is the initiator of continuous structural changes, which is of special importance for developing countries." Taking Serbia as an example, he further states: "Sudden and premature deindustrialization, transitional reforms and the applied strategy of economic development resulted in the devastation of industry." Serbia achieved a low level of industrial development, especially when compared to the Czech Republic, Slovakia, Hungary, and Slovenia" (Mićić, 2015). So, as it could be stated that countries in transition have come out of socialism, but are still stuck in a system that is closest to the concept of clientelistic capitalism.

Globalization led to the networking of economies and resulted in many benefits, such as the exchange of goods, people, and services. Yet, at the same time, it increased interdependence and caused a spill-over effect of negative economic repercussions, especially when the crisis emerged in the world's most developed countries. Therefore, authors believe that a holistic approach is needed for the new economic theory and paradigm that would take into account all aspects of social, economic, and political life that may impact an economic substance and macroeconomic developments, both on the national and supra-national level in the long run (Stiglitz, 2018; Keen, 2011; Dunleavy, et al., 2006).
To respond to the above task, economic authorities and many economic analysts found themselves competing to find a "new formula" of development, which would, through a multidisciplinary and multisectorial approach and reallocation of national factors of economic development and growth, establish an adequate roadmap in a rapidly changing environment. Similarly, Jakopin (2012) emphasizes the necessity of a shift of the focus on developmental factors: "The pre-crisis models of reallocation of growth factors have created a major gap in development and imbalances in the structure. All the post-crisis models regarding factors of growth are based (author's note) on industrial policies". Given the example of Serbia, he proves that "the model of transformation did not contribute to the sectoral reallocation of resources and the transitional productivity growth was not based on the effect of reallocation" (Jakopin, 2014)

According to the 2020 KOF Globalization Index, the leader is Switzerland, followed by the Netherlands, Belgium, Sweden, Great Britain, Austria, Germany, Denmark, Finland, and others. The Czech Republic is in thirteenth place, followed by Hungary in 14th place, and Slovakia in 19th. When it comes to the countries in the SEE region, Croatia is in 23rd place. It is followed by Slovenia (30), Serbia (36), Montenegro (55), Northern Macedonia (58), Bosnia and Herzegovina (64), Albania (75), and the like. If we link this indicator with other indicators, such as the level of global competitiveness, GDP per capita, etc., we see that countries that accepted the principles of globalization and became strongly involved in it show much better results. So, generally speaking, globalization can be said not to be "a priori" an obstacle to development. As an example, we can observe the pattern of development 
that the so-called "Asian tigers" (South Korea, Hong Kong, Taiwan), as well as some other newly industrialized countries that, riding on the waves of globalization, have approached or have reached the level of development of the highly developed countries.

To understand more clearly the direction we should look to, it should be pointed out that the literature of the mid- 80 s saw the rise of concepts, such as new economy, information economy, knowledge economy, and so on. At the same time, Daniel Bell offered the concept of a post-industrial society in which information, technology, and knowledge would be the key drivers of development (Lyon, 1986). Also, back in the early 1990s, Peter Drucker (1989) said the following: "Key features of a new society, similarly to the previous ones, will be new institutions, new theories, new technologies, and new problems". Following these predictions, today, right before our eyes, the nature of capitalism and character of production on the global scale are transforming themselves into a so-called global digital economy by creating a single planetary system that shifts itself from the oligarchy of the oil and gas, into the bio-information configuration and continues to develop the trends of formalization and quantification (Peters, 2019). Thus, in contrast to the underdeveloped world, there is the concept of "digital capitalism", which appeared in the military, government, and educational research networks that gave birth to the Internet in the early 1990s. In the times of "digital reasoning"- everything that can be automated will be automated, hence Marx's formula of the production function of the holy trinity of three factors - labor, the means of labor, and the objects of labor - loses its importance in the way that the workforce in "digital", "algorithmic", or capitalism of "intelligent systems" ceases to be the most important driving factor. Hence, we use Handy's (1996) argument to develop our application of the concept of change management and find a new balanced combination of production factors. He points out that if the combination (factor - author's opinion) is wrong, poorly balanced, or not changed when necessary - the result will be a phenomenon we call "sluggishness and relaxation, or insufficient efficiency, which is hidden cancer for the organization" (Handy, 1996). To conclude, what the creators of policy in the area of development, industry, and economy in developing countries should keep in mind is that if globalization has not succeeded in reducing the poverty rate, it means it has failed to ensure stability as well (Stiglitz, 2002). To make it more clear, globalization will not make itself more humane, effective, or equitable, but rather, countries in transition would have to fight for a better position on their own. To conclude, the dynamics of development of individual national economies will ever more dependent on their abilities and resolution to raise their competitiveness to a higher level by making more use of their knowledge.

D. Rodrik shares a similar view to Piketty's (2014), by emphasizing that international economic integration has caused internal disintegration in many countries, thus making the gap between the rich and the poor even wider (Rodrik, 2020). Transition countries face these problems that have many different aspects or features, such as high penetration of imports, immigrant inflows and high levels of public debt. Furthermore, these countries still lag far behind in terms of competitiveness, as in the current case of Montenegro. In this context, a more prominent role of the state in eliminating inequality becomes a necessity (Blanchard \& Rodrik, 2021). All these circumstances suggest that the state should 


\section{Journal of Contemporary Management Issues}

take on the role of "emergency entrepreneur", which is in line with the principles of efficiency of public administration, i.e. the tendency for public management to follow the logic of private-profit oriented sector, and as such be focused on efficiency and effectiveness, (Godenhjelm et al., 2015) have practice-oriented results, be measurable and accountable (Carroll, 2017). Effective and efficient public management involves the use of techniques for quality management, by focusing on sustainability and stakeholder involvement (Gnan et al., 2013).

\section{FORCED TRANSITION PATH AS A REFORM STAGNATION}

The question we are trying to answer here is: "Can the transition countries (region) ever catch up with the living standards of the world's most advanced market economies?" (Berglof, 2013)

To begin with, it is clear now more than ever that false socialism was dying out way too slowly, and the attempt to establish neoliberal capitalism failed. In most of the above-mentioned countries, reforms have gone the wrong way, but not by chance; one of the key conclusions of this paper is that building a modern state that would be based on clear legal foundations and rest on solid and well-organized institutions of the market economy was taking too long (Lojpur \& Koyama, 2002). The privatization that was carried out under the guise of "comprehensive transformation", with only minor differences, in most cases, shared similar characteristics such as violence, bureaucratic arbitrariness, omnipresent corruption and crime, and many other forms of injustice, which continues to this day.

It turned out that countries of SEE had no structural reforms, before or after the slowdown in economic growth during the crisis of 2008-2009, as evidenced in many reports on the so-called transition indicators (Lojpur et al., 2020). Also, it is a fact that other, less developed countries are deeply involved in the neoliberal international division of labor that had many and negative consequences for them. To be more precise, "this doctrine ignored the political experience from the Great Depression, which showed that the so-called 'invisible hand' of the market does not function efficiently or permanently, among other things, due to asymmetric information, externalities, irrational choices, etc. To reduce the risk of imbalance, we need the so-called 'visible hand' of the state" (Đuričin, 2011). Is it finally clear that only the state can eliminate the causes of current problems? This will not happen by itself without the help of the "invisible hand" of the market, so the state must take the role of "the agent of change" (Kotter,1996), or better to say "emergency entrepreneur", and with reindustrialization and structural change, must be the backbone of the new development paradigm.

On the other hand, not only countries in transition face challenges and issues. Global challenges that the EU faces are still the same, but they have gained momentum and complexity - continuous economic strengthening of emerging countries, reorganization of finances at the global level, climate change, and limited resources. These tendencies, as recognized by the EU development documents, such as e.g., "Strategy 2020", are especially valid for countries that have already "joined" the EU, but are often treated as "poor relatives" (Lojpur et al., 2020).

The presence of lagging countries in transition is suggested in the Transition Report (2018/19) of the European Bank for Reconstruction and Development. Based 
on the transition indicator that determines the transition progress of countries, countries in transition lag behind mostly in good governance, competitiveness, resilience, integration, and innovation. On the other hand, the only safe path to being competitive in a modern business arena for small countries is the path of knowledge (Lojpur \& Drašković, 2016). The application of the innovation-based development concept, especially through cooperation with external partners, contributes to higher added value, better economic results, and higher profits of companies (Strašek et al., 2020), and better economic performance of the state altogether. Furthermore, it should be understood that education and training, innovations, digital technologies, etc. are vital for the process of adapting to market changes and best business practices (Bukvić et al, 2020).

As additional arguments that support the abovementioned, we may make some assessments such as: How long (in years) would it take for the regional countries to reach the European standard in case that some of the most developed countries stagnated? In that sense, the average GDP growth rate for Montenegro, Serbia, B\&H, Macedonia, and Albania for the past fiveyear period is analyzed (see Table 1), and by using the trend extrapolation method, used to project the GDP per capita in the near future.

Table 1. Annual GDP growth rate 2015-2019 (\%)

\begin{tabular}{|l|l|l|l|l|l|l|}
\hline State/Year & $\mathbf{2 0 1 5}$ & $\mathbf{2 0 1 6}$ & $\mathbf{2 0 1 7}$ & $\mathbf{2 0 1 8}$ & $\mathbf{2 0 1 9}$ & Average rate in \% \\
\hline Montenegro & 3.33 & 2.93 & 4.71 & 5.10 & 3.64 & 3.94 \\
\hline Serbia & 2.28 & 3.88 & 2.59 & 4.96 & 4.75 & 3.69 \\
\hline Bosnia \& Herzegovina & 2.91 & 4.46 & 3.18 & 4.58 & 3.30 & 3.68 \\
\hline Macedonia & 3.78 & 2.78 & 1.02 & 2.67 & 3.53 & 2.76 \\
\hline Albania & 2.52 & 3.48 & 3.90 & 4.33 & 2.65 & 3.37 \\
\hline
\end{tabular}

Note: All values in USD.

Source: World Bank.

For the needs of its budget, Germany, one of the leading EU member states was taken as the reference country, whose GDP per capita was 47.628 USD at the end of 2019, according to the World Bank data. The results are worrying, as they indicate that some of the countries in the region would have to wait almost until the end of the century to reach the current living standard of Germany, even in the case that current positive trends continue, which is highly unlikely, given the COVID-19 pandemic. Thus, with the average annual GDP growth rate (per capita) for the past fiveyear period, Montenegro (Table 1) would reach the current level of development of Germany in 2064; Serbia would do that in 2072, Bosnia \& Herzegovina in 2076, Macedonia in 2098 and Albania in 2086.

Finally, instead of an answer, we will end this part of the paper by asking a new logical question: In the long run, could these development trends in this group of countries open the possibility of establishing some kind of "national development models", as was the case after the Great Depression (e.g. industrialization in Latin America), which would be a highly desirable alternative to neoliberal globalization, 


\section{Journal of Contemporary Management Issues}

and would ultimately result in some form of (re)globalization?

\section{NEW INDUSTRIAL POLICIES AS AN "EMERGENCY EXIT"}

Before the 2008-2009 global economic crisis, the prevailing view was that macroeconomic models, such as the Dynamic Stochastic General Equilibrium (DGSE) and Computational General Equilibrium (GGE) represent a credible overview of macroeconomic developments and a kind of mechanism that would help solve "chronic" economic problems of the real economy (Blanchard, 2009; Stiglitz, 2018). However, contrary to that, the global economic crisis has shown all the shortcomings of generally accepted economic thought, especially regarding an inadequate perception of the bigger picture, i.e. the complexity of factors influencing macroeconomic trends and tendencies. With this, traditional economic approaches, as if torn away from reality, became "blind" to the needs and demands of the new economic reality, especially in the transition post-communist economies, which have found themselves in the process of economic transformation (Papava, 2018).

In essence, industrial policy is a strategy adopted by the state that includes some measures and activities, i.e. mechanisms aimed at achieving specific goals of each industry, or the economy as a whole, which implies productivity, and significant contribution of industry to the growth of GDP. At the same time, industrial policy is concerned with an entire mix of a country's economic policies, so it is now even clearer why the matter of reindustrialization is at the very top of problems both in the EU and most countries in transition (Lojpur, 2020). While on the subject, the very notion of industrial policy has become legitimate in Europe once again, in terms of creating a more favorable environment for industrial development. This is an important element of overall development and European integrations, and the ultimate goal of implementation of any industrial policy is achieving economic growth and social stability. This signaled a turn in the way that development policies are run, and the so-called new approach to industrial policy began in the European Union in March 2000 in Lisbon, with the adoption of a comprehensive reform agenda entitled "Employment, economic reforms, and social cohesion - Towards a Europe of innovation and knowledge", known as "the Lisbon Strategy" (European Commission, 2000). The European Commission set a goal to support industrial modernization and to ensure European leadership at global markets in the context of the new industrial revolution and digital transformations (Savić \& Lutovac, 2017).

Unable to offer a good answer to questions from this paper, it is inevitable that we resort to someone who earned a place in the Pantheon of great economists during his lifetime - Joseph Schumpeter. So, in his writings on economic development and in explanation of how the economy overcomes the stationary state (crisis, recession), the patriarch of Western economic thought of the twentieth century excludes the non-economic factors that otherwise form an integral part of a competitive society: technical, political and social factors. In his opinion, interruption of the circular movement and the economic development is obtained through new combinations and innovations of production factors (Schumpeter, 1942). Thus, in the preface of the abovementioned historical Schumpeter's work, the late professor Z. Pjanić draws some very decisive conclusions that speak in favor of our argument that capitalism as a system grows, 
transforms itself, and reaches its peak in the form of a neoliberal concept and dies out. "It (capitalism)", points out professor Pjanić, "gives birth to political and social forces that ultimately destroy it" (Pjanić, 1975). Furthermore, he points out that "capitalism does not leave the historical stage because of economic difficulties, structural shortcomings of its economic system, economic maturity or technological stagnation, but because it creates a political climate that undermines and destroys it" (Pjanić, 1975). With the COVID-19 crisis, it is absolutely clear that the capitalist machine is overheated, that it does not function as it has in the past, or not nearly as effective as its supporters advocated. So, the question is "will capitalism stay alive?". Schumpeter (1942) concluded with a paradox, implying that "capitalism is destroyed by its success".

In today's world and the increasingly complex economy, the competitiveness of national economies is a result of the cooperation of many factors, and developed industrial countries are looking for new generators of development and lasting sources of competitiveness through the "fourth industrial revolution". In this sense, the experience of developed industrial countries shows that further development of industrial production based on digital technologies becomes the guiding force and basis for the development of medium-term development strategies and the battle for competitiveness among the world's most developed countries, such as the US, China, Japan and Sweden (Karabegović \& Karabegović, 2020). Thus, at the beginning of the $21^{\text {st }}$ century on "Hannover Messe 2011", the new $4^{\text {th }}$ industrial revolution was announced and referred to as the "Industry 4.0 " and promoted as a concept that marked the new German strategy for industrial development. In other words, "Industry 4.0" is the original name for the economic trend and direction in the development of the economy that dates back to the beginning of the last decade ${ }^{1}$. This concept focuses on maximum automation in production and data exchange, including cyber systems, as well as cloud computing technology, the Internet of Things, etc. Initially presented by the Government of the Republic of Germany, this concept requires a radical transformation of the economy, to maximize results in the process of creating a value chain through automation and the inclusion of all relevant factors in the production process.

It is no surprise that Germany is the country of origin of the "Industry 4.0" concept, considering that its industry is among the most competitive ones, and the country is a leader in the production of industrial equipment. The core of this strategy is the transformation of production systems in a way that they are adaptable to customer needs and the rapidly changing environment. According to some estimates, this concept has contributed to a reduction in production, logistics, and management costs between 10 and 30\% (Rojko, 2017). Also, additional benefits of the "Industry 4.0" strategy include a more flexible and friendly work environment, more efficient use of natural resources and energy, shortening the time needed to place products on the market, better customer orientation, and the ability to significantly increase production output without major growth in production costs.

The initiative, launched by Germany, was a pioneering endeavor and a beginning of new development and strategic path in the field of full digitalization and use of ICT technologies in the industry, as

\footnotetext{
It was announced and presented by Chancellor A. Merkel as an elaborate initiative of German entrepreneurs and scientists.
} 


\section{Journal of Contemporary Management Issues}

a basis for productivity growth in neoliberal economies. It has encouraged development, competitiveness, and development strategies in other countries, as well. Similarly, China's political leaders and holders of economic power were aware that long-term economic progress in the field of global competitiveness and the country's overall prosperity could not be built forever on the manufacturing and the "pollution-intensive" industries. China, as one of the contenders to become the world's leading economy, launched its development strategy, entitled "Made in China 2025". Being consistent in the implementation of this project, China sees the global economic race as a great chance to catch up with the US, in terms of technology and ultimately economics, as well as retain its primacy over other fast-growing world economies, leaving the cheap labor production to Vietnam, Cambodia, Laos and other underdeveloped countries.

In response to this Chinese action in industrial development, the United States initiated a project called "Advanced Manufacturing Partnership 2.0". In general, the US political scene widely agrees that the country needs formulated industrial policies aimed primarily at job creation, innovation, and the green economy. The Government of Japan responded to the project "Industry 4.0" with its strategy called "Revitalization and Robots Strategy" (Karabegović \& Karabegović, 2020). In this sense, owing to the use of IT technologies, integration and networking of production processes, we can conclude that the economic logic and the guiding idea behind the growth of profit rates caused the emergence of a new development paradigm and acceleration of industrial growth in the form of new industrial policies.
Given that the situation on the "domestic" market is not great and that something needs to change in terms of new incentives and new models of economic growth, professor Jurčić (2014) believes that "many countries are in crisis, but not as victims of the world economic crisis, but rather as a consequence of the lack of active industrial policy", where the idea of deindustrialization, according to this author, "is a consequence of leaving the domestic economy to "the invisible hand" at times when all smart countries have clear industrial policies and goals" (Jurčić, 2014). However, to overcome this situation, governments of developing countries have to implement structural reforms to improve their macroeconomic stability, diversify risks for their economies that are based on unnecessary reliance on natural resources only (such as the case of Montenegro - through reliance on tourism) and develop more efficient and resilient institutions, both in the political and legal sense.

\section{EXAMPLES AND IMPLICATIONS FOR CORPORATE MANAGEMENT}

It is a fact that the past is of no great use, the present is not seen and everything is undergoing radical changes before our eyes, rapidly and astonishingly; some other leaders (China and others) will take the position of world leaders, which imposes a new development paradigm for less developed countries as inevitable. Namely, everyone agrees that "the world will never be the same again", but few dare to comment about the future and actions that should be taken to have "a better world than any other in the past." Hence, the pursuit for a new pattern of success gives rise to a question that seems logical: Does capitalism 
have any future in its present form, and how should a "new" development path look like in the post-pandemic period in countries whose development stagnates?

Given that not much is certain in this particular case - the end of the pandemic is beyond our power and nowhere in sight, we treat our economic downturn with noneconomic methods (physical distancing) and keep repeating the mistake of 2008, meaning that we are primarily dealing with liquidity and social matters instead of being focused on solvency. In this crisis, the trend line might take the form of several "W"-s, with an extremely uncertain outcome (Vujović, 2008). In that sense, one of the ways to face an uncertain future is to abandon the current prevailing development paradigm and master the strategy of revolutionary changes, which would have the character of an economic reengineering at the national level.

As things stand now, the COVID-19 pandemic will further accelerate the existing crisis, making increasingly certain the further automation of society and confinement of individuals to narrow groups of virtual trust; strengthening of state controls that will not be fundamentally entrepreneurial; the emergence of sporadic conflicts within countries to "conquer" democracy and the relocation of the center of world power from the West (EU and US) to the Far East. Therefore, it may be useful to point out several alternative models of economic development that can be observed from examples of other countries and their practices. Among them, a successfully implemented model and an interesting one is the so-called „Asian model of development", coming from the countries, often referred to in the literature as the "Asian tigers" (South Korea, Singapore, Hong Kong, and Taiwan). This model represents a successful economic development strategy that many experts and economists agree on. When it comes to some of the key determinants of the development strategy that has contributed to their successful economic development and a fortunate position at the global level, the following can be singled out (Rowthorn et al., 1999):

- $\quad$ investment rates - high investment rates in providing new technologies and the construction of the necessary infrastructure, which were on average about $20 \%$ higher than in other regions of the world;

- macroeconomic basis - low inflation and high savings rates have influenced the development of the basis for investment in human and physical capital, and the encouragement of education as the foundation of economic development;

- outward orientation, with undervalued currency, to encourage exports with fiscal incentives, and monitoring of technological progress.

The above points out that these countries have changed their focus of development and directed it to investments and technology, social capital, and education. In doing so, and while relying on an outward orientation strategy, these countries took care of exports and technological progress by relying on the experience of their predecessors. Thus, they ensured the quality foundations of economic development and their current global position. At the same time, as we live in the age of discontinuity, uncertainty, high risk, and extreme complexities, adapting to changes or proactive actions and directing the changes themselves becomes conditio sine qua non. However, comparable to the individual (micro) level, the same rules apply to the mezzo level (a company), but also the macro-level 


\section{Journal of Contemporary Management Issues}

(national economy). In this context, the matter of an appropriate development paradigm of management and management of innovation in transition countries is particularly interesting. In this sense, in a limited range of possibilities, one of the solutions is the choice of introducing a new "development curve" that requires radical innovations, based on major, disruptive changes that are happening before our eyes, in economic, technological, and social terms. As a whole, that means the transformation of human behavior, companies, market reorganization, as well as key industries. Trends such as the aging of population and climate change, that call for proactive actions by governments and sustainable development policies, also point to a shift towards embracing the new. Likewise, previously mentioned rising inequality in wealth and growing geopolitical uncertainties further point to the importance of diversification of economies. This requires both flexible and dynamic strategies, as well as social stability at the national level.

Globally speaking, we can conclude that the existing, or better still, past models are almost exhausted in terms of the functioning of production processes, cost reduction, and savings through optimization in all phases of production. Hence, it was necessary to find a new generator of revenues, which will make the production process more efficient and effective through cost reduction, and this boils down to the need to create new industrial policies. "Since 2008 , i.e. since the beginning of the global economic crisis, fundamental drivers of economic activities have been Germany and several other member states" (Savić $\&$ Lutovac, 2017). Hence, the logical question is how to transform obsolete manufacturing industries into new industrial policies. Furthermore, what are the factors and where the new "triggers" for growth and development can be found? To the extent that this is possible in economics, with the "S" curve as a concept - the so-called "second curve" , it would be possible to confirm entrepreneurship in the form of entrepreneurial creation of resources, as a dominant driving factor of the new economic paradigm.

For the sake of better understanding, instead of the phrases, such as the "learning curve" or "moving ahead of the curve", which have been used in business to make future projections, the concept of "S-curve" is used as a metaphor, an idea that most readers are familiar with. Its author, C. Handy (2015) points out that most traditional ways of doing things in life, not just in economics, require " a new development curve", including capitalism, the education system, marriage, and the family, democracy and governance, etc. In doing so, as Handy points out, it is important to note that the goal is not to create a new development curve from the scratch, but quite the opposite. When the original development curve is in the ascending phase or is close to the peak, a sudden change should be made, as an innovative, development strategy enables survival, growth, and development over longer periods. In reality, it is a universal truth that the development curve of any organization, company, or state will take a downward path once it reaches its peak, as shown in Figure 1. However, it is important to understand that it can be extended or maintained over a longer time, as was the case, for example, with the Roman Empire, which lasted for 400 years. However, in the end, unless transformed in time, a decline is inevitable. (Handy, 2015).

\footnotetext{
2 It is often referred to as the 'double S-curve' model; "second-curve" or "two-curves" in the literature.
} 


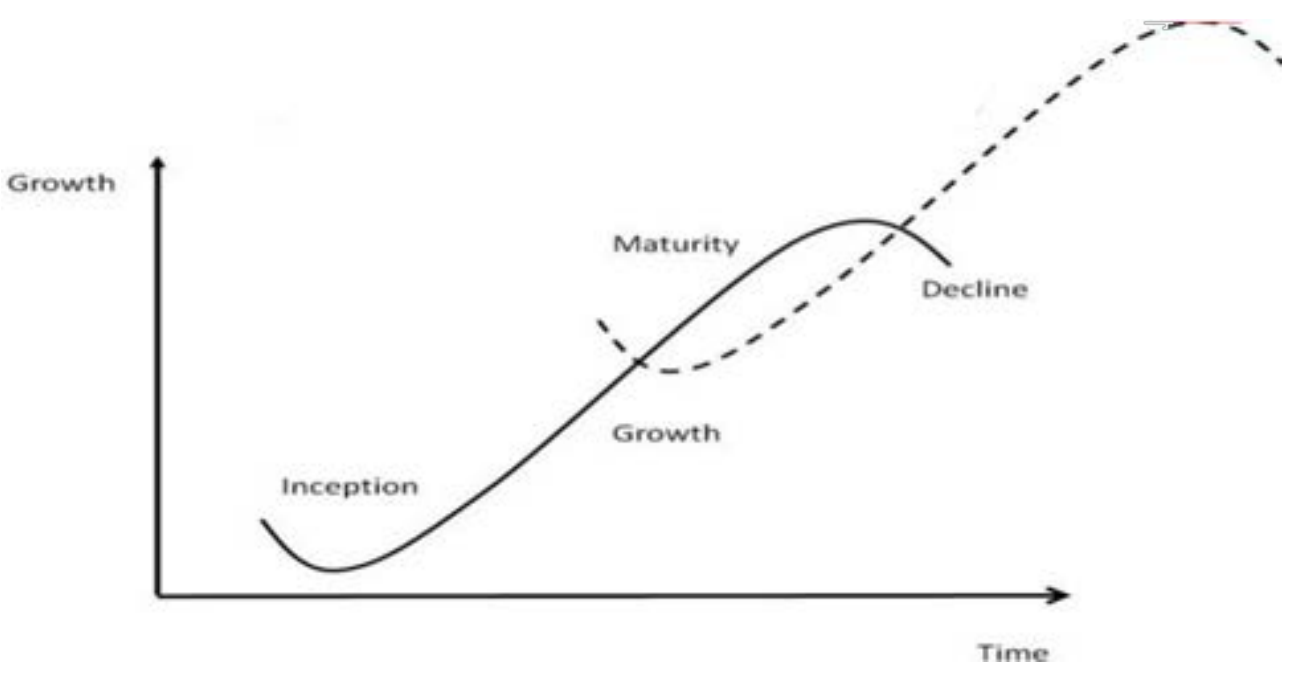

Figure 1. Handy's "second curve"

Source: Handy (2015)

The key point of the "second curve" is that progress sometimes requires radical life changes (be it a life of a person or a state), a new, different course (paradigm shift), and always a completely new understanding of problems. Practically, that is what T. Kuhn called the "paradigm shift" (Handy, 2015). However, the real problem is that a new change must begin, while the first curve is still in full force, meaning that those who were at the forefront during the first cycle must start thinking of a different way to take in the future or, more likely, help others to move forward in the new curve, and that may not be easy. The second curve, although the same in shape as the first one, is fundamentally different as it reflects future orientation and introduces personal, social, and economic transformation (Morrison, 1996). In that sense, the "second curve" is far-reaching and, in the long run, it affects people on a personal level, causes changes in the market, reorganizes corporations, and sometimes even transforms major industries (Morrison, 1996).

When we consider the possible application of the "second curve" as a concept of development, we believe that this is fully reflected in the new Chinese development strategy entitled "Strategy Made in China 2025". Namely, it implies a total turn of China's positioning on the international market and the transformation from an economy that is based on finished products of lower quality or lower level of technological processing, to a leader in the field of innovation and production of high-quality products to achieve high growth rates. This means stopping the decline in economic growth rates and taking advantage of the opportunities offered by the increasingly rich Chinese market. In the above project, the success of this goal depends on three groups of factors: the ability to develop innovative products, create internationally recognized brands and build modern production facilities. At the same time, the concept of "Made in China 2025" targets all high-tech industries that strongly contribute to economic development and higher rates of economic growth. The focus is primarily on the aerospace, automotive, and marine industries, robotics, the medical industry, etc. (Wübbeke et al, 2016). Unlike other socialist countries, it is important to point 


\section{Journal of Contemporary Management Issues}

out the fact that, from the very beginning, the foundation of China's economic success was a hybrid economic model run, by the state administration. It is evident that, if half of China's economic growth stems from market orientation, the second one is the result of an active policy of their government that has protected old economic structures, such as the state-owned enterprises. Simultaneously, those new industries are developed through a wide range of development policies, which can be seen as a transition to a "second curve" (Rodrik, 2020).

To fully understand and accept the concept of the "second curve", that we advocate in this paper, in the case of industrial policies, it would mean the acceptance of the following principles: favoring knowledge, technologies, and economic activities in those areas that improve economic performance, social conditions and environmental protection. Experience shows that modern new industrial policy encourages activities and industries that are characterized by the learning process, rapid technological change, economies of scale, and strong growth in demand and productivity. An excellent example is the creation of the Smart Specialization Strategy, which was adopted in 2014 by the European Commission. The EU has thus set priorities to build competitive advantage and encourage the region to focus on "horizontal" efforts to build a critical mass for research and development, innovation, and investment capacities in very specific activities, by combining advanced technologies and local competencies from traditional industries (Savić \& Lutovac, 2017).

In addition to the aforementioned, many additional examples are useful for understanding how the timely decision-making process and the perception of the need for change in the process of formulating the development strategy contribute to accepting the concept of the "second curve". One of the examples is related to the Scottish football coach Alex Ferguson, who coached Manchester United for 27 years. His attention was focused on promoting the young talents to the A-team before the current stars of the team reach or pass the peak of their football careers. In this way, he wanted the team's stars and new young players to together create the beginning of the "second" development curve, as the basis for Manchester United's success in the years to come. The keyword is "timing" and the greatest credit for Alex Ferguson's success lies in the timely transition to a new development curve, even though he may have been unaware of this management concept (Handy, 2015).

As shown by Figure 1, there is, or there was an initial investment period; there are results and the line grows, and if all goes well, it increases constantly; but, there comes a time when the curve reaches its peak and begins descending; this decline is often long-lasting, but there is always decadence at the end. Thus, e.g. according to the testimonies of associates and employees, Steve Jobs was a very "tough" person to work with. Despite this, he was a "master" of the concept of the "second curve". At the time when Macintosh made amazing results in terms of market share and profit, Jobs and his innovation team had already planned to enter the music market, which he did with the iPod. While the iPod was still growing and beginning to dominate the market, Jobs focused on designing the iPhone, and very quickly the iPad. Each new product was a "new curve" that started. while the previous one was still in the growth phase. These were extremely risky moves, as S. Jobs was conquering new markets, but from his perspective, they 
were logical and reasonable. Thanks to such leadership, Apple products are part of the lives of over a billion people worldwide. Available data say that one billion people used 1.4 billion Apple devices at the beginning of 2019 (Apple, 2019).

On the other hand, there is a negative example from Nokia. The basic motto of the Finnish manufacturer of mobile phones was that they are one of the few companies with the capacity to transform, change, develop and apply modern technologies following the needs of their consumers. In practice, however, they were far from being adaptable, did not respond adequately to competition (Apple and Samsung), and did not take advantage of Android technology for mobile operators. In the end, they very quickly fell victim to huge success in the field of classic mobile phone production. As a result, millions of customers abandoned them, and Microsoft bought Nokia in 2013. On that occasion, Nokia's CEO said: "We didn't do anything wrong, but somehow, we lost" (Handy, 2015). The keywords in this sentence are - we didn't do anything. They tucked away in their comfort zone, unable to react quickly to changes and move to a new development curve. The explanation is very simple, they have become experts in the production of mobile phones, but market demands have changed, unlike them. More precisely, Nokia overestimated the strength of its brand and believed that, despite their late entry to the smartphone market, they would be able to easily catch up with the competition; however, they stayed on the first curve for too long. In that sense, the fall of Nokia is the result of the company's hesitation to move to the "second curve" and start a new era. This example is an illustration of new challenges and problems of the new time that cannot be solved by traditional approaches (Handy, 2015).
Illustration of the "second curve" applicability is best understood from the statement of L. Light, McDonald's Marketing Director: "Today, you can own an idea for an hour and a half at most!" (Business Academy, 2015). Finally, the diagnostic health tool of an organization, developed by one of the greatest authorities in the field of management, Isaac Adizes, is based on the question: "What percentage of current income comes from products that were introduced over the course of the previous three years?" (Adizes, 2019). The higher the percentage, the healthier the organization in the healthier part of the life cycle. Consequently, taking into account the global business environment, the application of the S-curve becomes a prerequisite for business sustainability.

\section{CONCLUSION}

In line with the open questions vis-à-vis regional countries, owing to the systemic deformation of former socialist countries that blindly seized the imposed postulates of the Washington Consensus, suffering all the negative consequences of globalization and its paradigmatic concept, embodied in the form of a neoliberal model of overall socio-economic life, and given the context of the current COVID-19 pandemic, the crisis will deepen further.

To repeat the question from the introduction - is it possible, and how, to manage the development of countries in transition, to reintroduce inequality on the global scale. This paper suggests reindustrialization as a prerequisite for economic development. The focus on economic development, based on education, innovations, and the digital economy, will result in better economic performances of countries in transition and their competitiveness. A more 


\section{Journal of Contemporary Management Issues}

prominent role of the state becomes indispensable, and the state is expected to take on the role of the emergency entrepreneur in line with the principles of efficiency and effectiveness of public management and networking.

In the end, we conclude that those countries that were unsuccessful in implementing structural changes in their industry promptly lag and are slowly moving away from the traditional way of production. In the process of structural changes in the manufacturing industry from traditional to technologically more complex ones, the "second curve" can find a place of its own. However, in today's world, key drivers of quicker development across the globe are knowledge and skills, innovations, technology, the efficiency of resources, investments, activities of chain values, etc.

\section{REFERENCES}

1. Adizes, I. (2019). Tajne uspjeha: Moderne kompanije i lidestvo. Luštica Bay, KotorArt.

2. Apple (2019). Apple Reports Second Quarter Results. Press Release. Retrieved June 29, 2021, from https:// www.apple.com/newsroom/2019/04/ apple-reports-second-quarter-results.

3. Berglof, E. (2013). Stuck in transition?. Transition Report, London. European Bank for Reconstruction and Development.

4. Blanchard, O., \& Rodrik, D. (2021). Combating Inequality: Rethinking Government's Role, Cambridge. MIT Press.

5. Bukvić, I. B., Buljubašić, I., \& Ivić, M. (2020). Project management education in Croatia: a focus on the IT sector needs. Management - Journal of Contemporary Management Issues. 25(1), 255-278.

6. Business Academy (2015). Poslovne misli za sva vremena. Beograd. Link Group.

7. Carroll, J. J. (2017). Failure is an option: the entrepreneurial governance framework. Journal of Entrepreneurship and Public Policy, 6(1), 108-126.

8. Drucker, P. F. 1. (1989). The new realities: in government and politics, in economics and business, in society and world view. New York: Harper \& Row.

9. Dunleavy, P., Margetts, H., Bastow, S., \& Tinkler, J. (2006). New public management is dead-long live digital-era governance. Journal of public administration research and theory. 16(3), 467-494.

10. Đuričin, D. (2011). Anti-krizni program u 2011. i strategija održivog razvoja. Ekonomika preduzeća. 59 (12), 1-20.

11. EU Commission (2000). eEurope. An information society for all. Progress report for the special European Council on employment, economic reforms and social cohesion - Towards a Europe based on innovation and knowledge. Lisbon, 23-24 March 2000. Retrieved June 29, 2021, from: https:// eur-lex.europa.eu/legal-content/EN/ TXT/?uri=CELEX\%3A52000IE0244

12. Global, P. W. C. (2017). The long view: How will the global economic order change by 2050?, London. PriceWaterhouseCoopers.

13. Gnan, L., Hinna, A., Monteduro, F., \& Scarozza, D. (2013). The movement beyond the new public management: public governance practices in Italian public organisations. In Conceptualizing and researching 
governance in public and non-profit organizations. Emerald Group Publishing Limited. 117-150.

14. Godenhjelm, S., Lundin, R. A., \& Sjöblom, S. (2015). Projectification in the public sector-the case of the European Union. International Journal of Managing Projects in Business. 8(2), 324-348.

15. Handy, C. (1996). Gods of Management: The changing Work of Organization, London. Oxford University Press.

16. Handy, C. (2015). The second curve; Thoughts on Reinventing Society, London. Penguin Random House.

17. Jakopin, E. (2012). Postkrizna realokacija faktora rasta. Ekonomski horizonti. 14(2), 77-87.

18. Jakopin, E. (2014). Transfromacija modela rasta i razvoja - Institucionalne promene kao determinanta privrednog razvoja Srbije, Beograd. Ekonomski fakultet.

19. Jurčić, Lj. \& Vojnić, D. (2010). Quo vadis Croatia? Tridesetogodišnja stagnacija u svjetlu naše novije ekonomske povijesti. Ekonomski pregled, 61(12) 793-851.

20. Jurčić, Lj. (2011). Država blagostanja. MadeIn, March 2011.

21. Jurčić, Lj. (2014). Industrijska politika u globalnim procesima. Acta Economica, 13(1), 117-128.

22. Karabegović, I. \& Karabegović, E. (2020). Worker safety is increased by application of collaborative robots in the production processes Industry 4.0. Sigurnost: časopis za sigurnost $u$ radnoj $i$ životnoj okolini, 62(1). 11-18.

23. KOF Swiss Economic Institute (2019). Index of Globalization, Zurich. Press Release.
24. Kotter, J. (1996). Leading Change, Boston. Harvard Business School Press.

25. Langer, J., Alfirević, N., \& Pavičić, J. (2017). Organizational change in transition societies, London. Routledge.

26. Lojpur, A., \& Koyama, Y. (2002). Lessons from Privatization, Annual Report of Economics, Niigata. Nigata University, Faculty of Economics.

27. Lojpur, A., \& Drašković, V. (2016). Zemlje u tranziciji u uslovima globalizacije. Budućnost koju je neko drugi osmislio. International symposium; Banja Vrućica.

28. Lojpur, A. S., Radević, I., Lojpur, A. A., \& Martinović, N. (2020). Is the Recovery of Transition Countries Possible on the New Global Stage and How?. International Journal of Management Science and Business Administration. 6(1), 19-30.

29. Lyon, D. (1986). From 'PostIndustrialism' to 'Information Society': A New Social Transformation? Sociology, 20(4), 577-588. Retrieved June 29, 2021, from: http://www.jstor. org/stable/42854342

30. Mićić, V. (2015). Ponovna industrijalizacija i strukturne promene u funkciji ekonomskog razvoja Republike Srbije. Ekonomski horizonti. 17(1), 15-31.

31. Morrison, J. I. (1996). The second curve: Managing the velocity of change, New York. Random House.

32. Papava, V. (2018). Catching Up and Catch-Up Effect: Economic Growth in Post-Communist Europe (Lessons from the European Union and the Eastern Partnership States). European Journal of Economic Studies. 7(2), 109-125.

33. Peters, M. A. (2019). What Can Universities Do About the Future of 


\section{Journal of Contemporary Management Issues}

Work?. Higher Education in the World 7. 1(1), 309-315.

34. Piketty, T. (2014). Kapital u XXI veku, Novi Sad. Sociološko naučno društvo Srbije.

35. Pjanić, Z. (1975). Kriza savremenog kapitalizma. Beograd. RTB.

36. Rodrik, D. (2020). Why does globalization fuel populism? Economics, culture, and the rise of right-wing populism, Cambridge. National Bureau of Economic Research.

37. Rojko, A. (2017). Industry 4.0 concept: Background and overview. International Journal of Interactive Mobile Technologies, 11(5), 77-90.

38. Rowthorn, C., Andrew, D., Hellander, P. \& Lindenmayer, C. (1999.). Malaysia, Singapure \& Brunei. Loney Hawthorn. Planet Publications, 516-521.

39. Savić, Lj. \& Lutovac, M. (2017). Novi koncept industrijske politike u evropskoj uniji. Ekonomske ideje i praksa, 25(1). 7-22.
40. Schumpeter, J. A. (1942). Capitalism, Socialism, and Democracy. New York. Harper.

41. Stiglitz, J. (2002). Protivrečnosti globalizacije, Beograd. SBM-x.

42. Stiglitz, J. (2004). Globalizacija i njene protivriječnosti, Zagreb. Algoritam.

43. Stiglitz, J. E. (2018). Where modern macroeconomics went wrong? Oxford Review of Economic Policy, 34(1-2), 70-106.

44. Strašek, A., Pušavec, F., \& Likar, B. (2020). Open innovation and business performance improvement in strategic business alliances. Management Journal of Contemporary Management Issues. 25(1), 133-144.

45. Vujović, D. (2008). Globalna finansijska kriza-poruke i pouke za kasne tranzicione privrede. Ekonomika preduzeća. 56(1-2), 28-38.

46. Wübbeke, J., Meissner, M., Zenglein, M. J., Ives, J. \& Conrad, B. (2016). Made in China 2025. Mercator Institute for China Studies, 2(1), 14-41. 


\section{KONCEPT "DRUGE KRIVULJE" KAO KLJUČNI POKRETAČ GOSPODARSKOG RAZVOJA NOVONASTALIH TRŽIŠTA}

Sažetak

\begin{abstract}
Rad započinje s konstatacijom da je tridesetogodišnji process tranzicije iz socijalističkog $u$ tržišno gospodarstvo, kao integralni dio sveobuhvatnih promjena u istočnoj Europi - kako političkih, tako i ideoloških, $i$ dalje problematičan te trajan proces. U slučaju manje razvijenih ili tranzicijskih zemalja, s posebnim naglaskom na države zapadnog Balkana, popularno je mišljenje da je utjecaj deindustrijalizacije na zemlje u tranziciji jedanko bolan i radikalan, kao što je bilo $i$ uvođenje socijalističkog poretka. Stoga, kada se raspravlja o potrebi nove razvojne formule, vrlo je značajno ukazati na činjenicu da u današnjem, multi-polarnom svijetu nedostaju dobro utemeljene razvojne paradigme, pri čemu posebno treba uzeti u obzir očitu stagnaciju reformi, odnosno tzv. reformski neuspjeh. Prema mišljenju autora,
\end{abstract}

krizu nedovoljno razvijenih i tranzicijskih zemalja moguće je okončati samo uvođenjem novog ustrojstva, odnosno pronalaskom novog gospodarske razvojne paradigme. U svjetlu prethodnog izlaganja, u ovom se radu ustvrđuje da je potrebno zamijeniti postojeće tranzicijske modele ekonomske transformacije strategijama preokreta, zasnovanim na reindustrijalizaciji, tj. na novim industrijskim politikama. Na kraju, ovakav bi pristup podrazumijevao primjenu koncepta „,druge krivulje“ (,,S-krivulje“) u procesima upravljanja promjenama.

Ključne riječi: globalizacija, menadžment, neo-liberalizam, nove industrijske politike, koncept druge krivulje (,,S-krivulje“) 